\title{
Osmo Dehydration of Pineapple Fruits: An Overall Review
}

\author{
Nazaneen NS ${ }^{1}$, Senapati AK ${ }^{1 *}$, Dev Raj $^{1}$ and Mahanand SS ${ }^{2}$
}

${ }^{1}$ Centre of Excellence on Post Harvest Technology, Aspee College of Horticulture and Forestry, Navsari Agricultural University, Gujrat, India

${ }^{2}$ Department of Fisheries Engineering, College of Fisheries, Central Agricultural University, Manipur, India

\begin{abstract}
Application of osmotic dehydration for different fruits has been increased significantly in recent years. Among different fruits, pineapple have characteristic pleasant flavour, distinct aroma and exquisite taste and ranks $6^{\text {th }}$ position in world fruit production and is one of the most suitable fruit used for osmotic dehydration. Osmo dehydration is one of the relatively simple preservation techniques for processing of fruits which does not require any sophisticated equipments. So, the pineapple growers can use such type of technique and can convert pineapples into dehydrated form during the excess production during glut season and to reduce huge post harvest losses. In the osmotic dehydration process, partial dehydration of the fruit pieces is accomplished by dipping in concentrated sugar syrup solution followed by hot air dehydration. It is a useful technique for producing safe, stable, nutritious, tasty, economical and concentrated fruit products. The products prepared from pineapple by osmo-dehydration process remain good up to six months of storage at room temperature. COEX nitrogen package followed by storage at low temperature $\left(7^{\circ} \mathrm{C} \pm\right.$ $1^{\circ} \mathrm{C}$ ) and aluminum pouches maintain the quality of the product for long period.
\end{abstract}

Keywords: Pineapple; Osmo-dehydration; Quality; Packaging; Storage

\section{Introduction}

Fruits and vegetables play an important role in human nutrition. Besides supplying complex carbohydrates and proteins, the fruits are vital sources of essential minerals, vitamins and dietary fiber [1]. Pineapple (Ananas comosus (L.) Merr.) is one of the commercially important fruit crops of tropical world. The origin of the pineapple is the American continent, probably Brazil and Paraguay. It has spread throughout tropical and subtropical regions as a commercial fruit crop. Pineapple ranks $6^{\text {th }}$ position in world fruit production. The main producer countries reported are Brazil (2.21 million tons), Philippines (2.17 million tons), Costa Rica (1.98 million tons), Thailand (1.92 million tons) and China with 1.52 million tons [2]. The important pineapple growing countries of the world are the Hawaiian Islands, Philippines, Malaysia, Thailand, Brazil, Ghana, Kenya, Mexico, Taiwan, South Africa, Australia, Puerto Rico and India. Currently, India produces 1.57 million tonnes of pineapple with productivity of $14.93 \mathrm{t} /$ ha. In India, pineapple shares $1.9 \%$ of total fruit production of fruits [3]. Pineapple is a fruit appreciated by consumers around the world, mainly due to its sensory characteristics and characteristic pleasant flavour, distinct aroma, exquisite taste and absence of seeds. It is a good source of carotene and ascorbic acid, and is fairly rich in vitamin $\mathrm{B}$ and $\mathrm{B}_{2}$ [47]. It also contains phosphorus and minerals like calcium, magnesium, potassium and iron [8-11]. Furthermore, this fruit contains a proteolytic enzyme called bromelin, which aids in reducing inflammations and also contributes to good digestion $[12,13]$. It is used as a constituent of several home remedies and folk medicines. India produces more than $8 \%$ of total world production of pineapple. The major pineapple producing states in India are West Bengal, Assam, Karnataka, Tripura, Bihar, Manipur, Meghalaya, Nagaland, Kerala, Arunachal Pradesh, Andaman and Nikobar Islands, Goa, Jharkhand, Madhya Pradesh, Mizoram, Odisha, Sikkim, Tamil Nadu and Uttarakhand [14,15]. The year wise production status, area and productivity of pineapple in India are presented in Table 1 [16-18]. Value addition has become the watchword as it involves processing and preservation of the commodities which otherwise get disposed at cheaper price or lost without intellectual and technical inputs. In order to prevent losses, avoid gluts in the season and to ensure optimum utilization, it is required to subject these perishables for processing into more stable value-added products.

\begin{tabular}{|c|c|c|c|}
\hline Year & Area (000 HA) & Production (000 MT) & Productivity (T/HA) \\
\hline $2006-2007$ & 86 & 1362 & 15.8 \\
\hline $2007-2008$ & 80 & 1216 & 15.1 \\
\hline $2008-2009$ & 84 & 1341 & 16.0 \\
\hline $2009-2010$ & 92 & 1387 & 15.1 \\
\hline $2010-2011$ & 89 & 1415 & 15.9 \\
\hline $2011-2012$ & 102 & 1500 & 14.7 \\
\hline $2012-2013$ & 105 & 1571 & 14.9 \\
\hline HA: Hectare; MT: Metric tonne; T/HA: Tonne/Hectare
\end{tabular}

Table 1: Year wise production status, area and productivity of pineapple in India.

The nutritional composition of pineapple fruit (per $100 \mathrm{~g}$ pulp) is illustrated in Table 2 [18].

\section{Literature Review}

\section{Osmotic dehydration}

It is a process that entails the partial removal of water from fruits which is based on a tendency to reach equilibrium between osmotic pressure inside the biological cells (fruit) and the surrounding osmotic solution, which has an increased osmotic pressure caused by high concentration of soluble osmotic agent. The mechanism behinds that molecular diffusion of water through semi-permeable membranes takes place and fruit loses its water. Some soluble solids present in the solution may be taken up by the material and part of the soluble solids present in the original material may leach in the solution [19-23]. The osmotic dehydration process is stopped when the osmotic pressure inside the tissue reaches the osmotic pressure of the surrounding syrup

*Corresponding author: Senapati AK, Centre of Excellence on Post Harvest Technology, Aspee College of Horticulture and Forestry, Navsari Agricultural University, Navsari-396450, Gujarat, India, Tel: +912637282145; E-mail: ashoksenapati.iitkgp@gmail.com

Received July 19, 2017; Accepted August 07, 2017; Published August 14, 2017

Citation: Nazaneen NS, Senapati AK, Raj D, Mahanand SS (2017) Osmo Dehydration of Pineapple Fruits: An Overall Review. J Food Process Technol 8: 689. doi: $10.4172 / 2157-7110.1000689$

Copyright: (c) 2017 Nazaneen NS, et al. This is an open-access article distributed under the terms of the Creative Commons Attribution License, which permits unrestricted use, distribution, and reproduction in any medium, provided the original author and source are credited. 


\begin{tabular}{|c|c|}
\hline Composition & Level \\
\hline Water $(\mathrm{g})$ & 87.00 \\
\hline Protein $(\mathrm{g})$ & 0.60 \\
\hline Fat $(\mathrm{g})$ & 0.10 \\
\hline Carbohydrate $(\mathrm{g})$ & 12.30 \\
\hline Calcium $(\mathrm{mg})$ & 12.00 \\
\hline Phosphorus $(\mathrm{mg})$ & 10.00 \\
\hline Iron $(\mathrm{mg})$ & 0.40 \\
\hline Potassium $(\mathrm{mg})$ & 250.00 \\
\hline Sodium $(\mathrm{mg})$ & 1.50 \\
\hline Copper $(\mathrm{mg})$ & 0.08 \\
\hline Magnesium $(\mathrm{mg})$ & 17.00 \\
\hline Carotene $(\mathrm{lu})$ & 50.00 \\
\hline Vitamin $\mathrm{B}_{1}(\mathrm{mg})$ & 0.02 \\
\hline Vitamin $\mathrm{B}_{2}(\mathrm{mg})$ & 0.12 \\
\hline Folic acid $(\mathrm{mg})$ & 4.00 \\
\hline Ascorbic acid $(\mathrm{mg})$ & 50.00 \\
\hline Energy $(\mathrm{calories})$ & 50.00 \\
\hline
\end{tabular}

Table 2: Nutritional composition of pineapple fruit (per $100 \mathrm{~g}$ pulp).

\section{Selection of fruit}

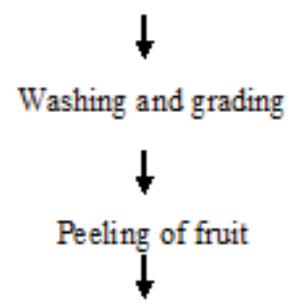

Preparation of fruit pieces

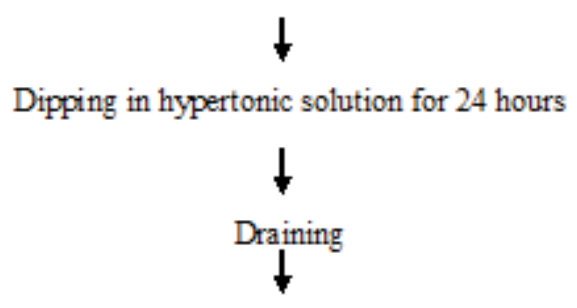

Drying in cabinet dryer $\left(60^{\circ} \mathrm{C}\right)$

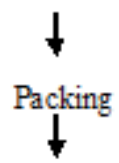

Storage

Figure 1: Process flow chart for the preparation of osmo-dehydrated pineapple pieces.

[24]. Osmotic dehydration has received greater attention in recent years as intermediate step for drying of several fruits and vegetables [25]. Being a simple process, it has potential advantage for the processing industry for dehydration of fruits with longer shelf life [26-29].

Osmotic dehydration is a useful technique for the production of safe, stable, nutritious, tasty, economical \& concentrated food obtained by placing the fruit slices in an aqueous solution of sugar with high osmotic pressure. The interest in inducing osmotic process in conventional dehydration has two objectives.

\section{Quality improvement}

Energy savings: In the osmotic dehydration process, partial dehydration of the fruit pieces by dipping in concentrated sugar syrup (hypertonic) for $20 \mathrm{hr}$ to $24 \mathrm{hr}$ followed by hot air dehydration at $50^{\circ} \mathrm{C}$ to $60^{\circ} \mathrm{C}$ temperature is done [28]. Because, generally osmotic concentration process will not give a product of low enough moisture content to be considered shelf-stable. The product must be dried further by air or freeze-drying methods for a reasonable shelf-stable product [30]. In this method, considerable energy is saved as compared to other methods such as osmo-convective, osmo-vac or osmo-freeze dehydration. Osmotic dehydration is one of the ways of processing fruits a relatively simple preservation technique that does not require any sophisticated equipment's [31-33] and it is also one of the potential preservation techniques for producing high quality products [32]. Even at rural places and remote areas without much technological knowhow, the growers can be used the technique and converted the excess production into dehydrated form and the product can be marketed for either use in fruit salads during off-seasons or can be used as a substitute for chocolates or candies. Osmotic dehydration is a food preservation technique that relies on the reduction of water activity and humidity of the product, which has advantages over other dehydration techniques because it preserves the sensory and nutritional characteristics of food $[34,35]$ as it provides minimum thermal degradation of nutrients due to low temperature water removal process reported by some recent studies [36-40]. Its process involves simultaneous water loss and solute gain [41] in which the mass transfer depends on variables such as type and concentration of osmotic agents, temperature, agitation/circulation of solution, solution to sample ratio, thickness of food material and pretreatment suggested by Rosa and Giroux [42]; Corzo and Gomez [43]; Kumar and Sagar [44] and fruit/syrup ratio by Fernandes et al. [45]. Osmo-dehydrated products are also called as intermediate moisture products. Osmo-dehydrated products stored at low temperature remain more acceptable compare to room temperature $[1,43]$. Osmotic dehydration process has several advantages, viz., (1) Quality improvement, (2) Energy efficiency, (3) Reduction in packaging and distribution costs, (4) Avoiding chemical treatment and (5) Product stability during storage [40].

\section{Suitable pineapple varieties for osmotic dehydration}

Kew: The average fruit weighs $1.5 \mathrm{~kg}$ to $2.5 \mathrm{~kg}$ and oblongs in shape. Eyes are broad and shallow. The fruit is yellow, almost fibreless and very juicy with $0.6 \%$ to $1.2 \%$ acidity; TSS varies from $12^{\circ}$ to $16^{\circ}$ Brix. Queen or Common Queen: The average fruit weight of pineapple is 0.9 to $1.3 \mathrm{~kg}$. Eyes are small and prominent. When fully mature, the fruit is golden-yellow. The flesh is less juicy, crispy, less fibrous, and transparent with pleasant aroma and flavor. The TSS content varies from $15^{\circ}$ to $16^{\circ}$. Brix and acidity between $0.6 \%$ to $0.8 \%$ [44-47]. Singapore Spanish: The fruit is cylindrical in shape; the average weight is about $1.6 \mathrm{~kg}$ to $2.3 \mathrm{~kg}$. The ripe fruit is reddish orange and flesh is golden-yellow, fibrous and good flavoured.

\section{Osmo-dehydrated pineapple}

Processed and value-added products are gaining importance in the worldwide markets. According to Silva et al. [48], to prolong the postharvest life of agricultural products, one alternative is water removal. Pineapples, for instance, can be peeled, cut into pieces and dried (Figure 1). Conventional drying is an expensive operation due to the phase change of the water from liquid to vapour. Thus, a pretreatment such 


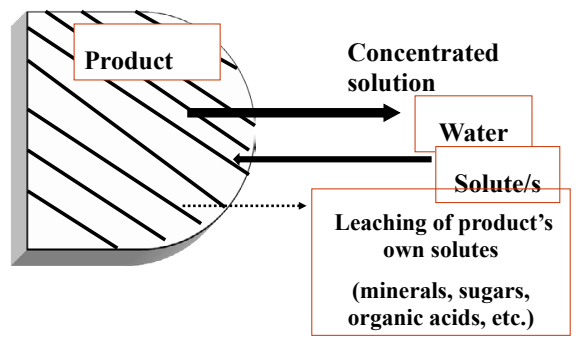

Figure 2: Schematic drawing of mass transfer during soaking process [39]

\begin{tabular}{|c|c|c|}
\hline Particulars & Raw pineapple & Osmo-dehydrated pineapple \\
\hline Moisture (\%) & 83.60 & 12.72 \\
\hline Acidity $(\%)$ & 0.66 & 1.50 \\
\hline Ascorbic acid $(\mathrm{mg} / 100 \mathrm{~g})$ & 33.57 & 25.77 \\
\hline Carotinoids $(\mu \mathrm{g} / 100 \mathrm{~g})$ & 945.42 & 603.75 \\
\hline Total sugar $(\%)$ & 13.76 & 65.64 \\
\hline Reducing sugar $(\%)$ & 6.44 & 38.34 \\
\hline Non-reducing sugar $(\%)$ & 7.32 & 27.33 \\
\hline Sugar: acid ratio & 20.85 & 43.85 \\
\hline
\end{tabular}

Table 3: Physico-chemical composition of raw and osmo-dehydrated pineapple [43].

\begin{tabular}{|c|c|c|}
\hline $\begin{array}{c}\text { Osmotic } \\
\text { agent }\end{array}$ & Remark & Reference \\
\hline $\begin{array}{l}\text { Sucrose/ } \\
\text { Sugar }\end{array}$ & $\begin{array}{l}\text { Dry sugar is unsuitable because of oxidative } \\
\text { browning during osmosis. Difficulty in disposing } \\
\text { sugar syrup. Sugar solution is best as it reduces } \\
\text { browning by preventing the entry of oxygen. } \\
\text { Sweetness hinders its use in vegetable processing. }\end{array}$ & $\begin{array}{l}\text { Farkas and } \\
\text { Lazer [1]; } \\
\text { Pointing et al. } \\
\text { [7]; Flink [15] }\end{array}$ \\
\hline $\begin{array}{l}\text { Calcium } \\
\text { chloride }\end{array}$ & $\begin{array}{l}\text { Increases the firmness of apple slices and } \\
\text { preserves the texture during storage. Prevents } \\
\text { browning because of synergistic effect with } \\
\text { ascorbic acid or sulphur dioxide. Imparts better } \\
\text { taste to the product if used above } 0.5 \% \text { level. }\end{array}$ & Pointing [4] \\
\hline Ethanol & $\begin{array}{l}\text { Decreases viscosity and freezing and freezing } \\
\text { point of the osmotic solution in cooling and freezing } \\
\text { processes. }\end{array}$ & $\begin{array}{l}\text { Biswal and Le } \\
\text { Maguer [7] }\end{array}$ \\
\hline Invert sugar & $\begin{array}{l}\text { Theoretically more effective than same } \\
\text { concentration of sucrose because when completely } \\
\text { inverted, it has twice as many molecules per unit } \\
\text { volume. Practically little difference in the rate of } \\
\text { osmotic dehydration of fruit by sucrose or invert } \\
\text { syrups of the same concentration and temperature. }\end{array}$ & \\
\hline Fructose & $\begin{array}{l}\text { Increases the dry matter content by } 50 \% \text { as } \\
\text { compared to sucrose due to higher penetration } \\
\text { rate. Water activity of the final product is also lower. } \\
\text { However, sucrose is preferred over fructose. }\end{array}$ & Bolin et al. [10] \\
\hline $\begin{array}{l}\text { Starch/corn } \\
\text { syrup }\end{array}$ & $\begin{array}{l}\text { Favours similar final water content with minimal } \\
\text { solid gain as that obtained with sucrose. }\end{array}$ & Flink [15] \\
\hline Lactose & $\begin{array}{l}\text { It has much lower level of sweetness than sucrose. } \\
\text { Low solubility in aqueous solution. }\end{array}$ & $\begin{array}{l}\text { Hawkes and } \\
\text { Flink [17] }\end{array}$ \\
\hline Malto dextrin & $\begin{array}{l}\text { It can be used as an osmosis solute at higher total } \\
\text { solids concentration, or in mixed systems. Less } \\
\text { effective than sucrose at the same concentration. }\end{array}$ & $\begin{array}{l}\text { Hawkes and } \\
\text { Flink [17] }\end{array}$ \\
\hline $\begin{array}{l}\text { Sodium } \\
\text { chloride }\end{array}$ & $\begin{array}{l}\text { NaCl: Mostly used for vegetables as it retards } \\
\text { oxidative and non-enzymatic browning. Increases } \\
\text { the driving force for the drying owing to the lowering } \\
\text { capacity of the salt. Sometimes blanching effect on } \\
\text { coloured products can be prevented using mixture } \\
\text { of salt and sugar. Organoleptic should be } 10-12 \text { per } \\
\text { cent. Hinders shrinkage at the surface layers. }\end{array}$ & $\begin{array}{l}\text { Hawkes and } \\
\text { Flink [17]; } \\
\text { Lenart and } \\
\text { Flink [22] }\end{array}$ \\
\hline
\end{tabular}

Table 4: Different osmotic agents and their effects in osmotic dehydration process.

as osmotic dehydration is normally used [41] and it showed that water loss from pineapple pieces increased with the increase of sugar solution temperature and concentration. Osmo-dehydrated pineapple pieces using $60^{\circ}$ Brix sugar syrup concentration with $60^{\circ} \mathrm{C}$ drying temperature produced better quality product with respect to physico-chemical as well as sensory quality up to six months of storage period [43]. Kumar and Sagar [24] suggested that tissue damage due to too high temperature and high solute concentration causes a dramatic decrease in solid gain efficiency. To improve the quality of osmo-dehydrated product pretreatment with potassium meta-bisulphite at $1.5 \%$ for $8 \mathrm{~h}$ was proved to be best reported by Ahsan et al. [2]. The sugar gain increased up to $50^{\circ} \mathrm{C}$ and then fell rapidly and it also increased with the increase in solution concentration. Pokharkar and Prasad [38] determined that osmotically concentrated pineapple slices at $30^{\circ} \mathrm{C}$ and 0.5 water activity gave a moisture content of $12.5 \%$ (dry basis). The schematic drawing of mass transfer during soaking process of osmodehydration is illustrated in Figure 2 [42].

Mehta et al. [33] reported decreasing trend in acidity (\%), total sugar (\%) $\mathrm{SO}_{2}(\mathrm{ppm})$, reconstitution ratio and increasing trend in reducing sugar (\%), moisture (\%) and dehydration ratio of pineapple rings during six months of storage period. Physico-chemical composition of raw and osmo-dehydrated pineapple pieces is mentioned in Table 3 [43].

\section{Discussion}

In order to prevent absorption of moisture from atmosphere and to prevent spoilage due to contamination of osmo-dehydrated pineapple pieces, different packaging materials are used such as aluminum foil laminated polyethylene pouches, high density polyethylene pouches (HDPE). Kumar et al. (2008) suggested that COEX nitrogen package followed by storage at low temperature $\left(7^{\circ} \mathrm{C} \pm 1^{\circ} \mathrm{C}\right)$ was found to be best for packing conditions judged at six months of storage. It retained higher carotene, ascorbic acid, sugar, rehydration ratio, less moisture, sensory score and non-enzymatic browning (NEB) in the product after six months of storage. The samples packed in laminated aluminum pouches were also found acceptable after storage of six months [2]. The different osmotic agents and their effects in osmotic dehydration process are presented in Table 4 .

\section{Conclusion}

Review of osmo-dehydrated pineapple reveals that to prolong the post-harvest life of agricultural products water removal is one of the alternative. Osmo-dehydrated pineapple pieces using $60^{\circ}$ Brix sugar syrup concentration with $60^{\circ} \mathrm{C}$ drying temperature produced better quality product with respect to physico-chemical as well as sensory quality up to six months of storage period, as too high temperature and high solute concentration causes a dramatic decrease in solid gain efficiency due to tissue damage. Potassium meta-bisulphite pre-treatment at $1.5 \%$ for $8 \mathrm{~h}$ before osmosis improve the quality of osmo-dehydrated product. COEX nitrogen package followed by storage at low temperature $\left(7^{\circ} \mathrm{C} \pm 1^{\circ} \mathrm{C}\right)$ is recommended for better quality. Considerable energy can be saved by osmo-air dehydration as compared to other methods such as osmo-convective, osmo-vac or osmo-freeze dehydration.

\section{References}

1. Farkas DF, Lazor ME (1969) Osmotic dehydration of apple pieces. Effect of temperature and syrup concentration. J Food Sci Technol 23: 668-690.

2. Ahsan H, Rehman W, Wani SM, Dar BN, Dalal MR, et al. (2008) Influence of potassium metabisulphite pre-treatment, osmotic dip and packaging materials on dehydration and some chemical properties of apple rings. Appl Biol Res 10: 31-35.

3. Rastogi NK, Raghavarao KSMS, Niranjan K, Knorr D (2002) Recent developments in osmotic dehydration: Method to enhance mass transfer. $\mathrm{Tr}$ Food Sci Technol 13: 48-59. 
Citation: Nazaneen NS, Senapati AK, Raj D, Mahanand SS (2017) Osmo Dehydration of Pineapple Fruits: An Overall Review. J Food Process Technol 8: 689. doi: 10.4172/2157-7110.1000689

4. Pointing JD (1973) Osmotic dehydration of fruits, recent modifications and applications. J Process Bio Technol 12: 8-20.

5. Lodh SB, Diwaker NG, Chadha KL, Melanta KR, Selvaraj Y (1973) Biochemical changes associated with growth and development of pineapple fruits var. KewIII. Indian J Hort 30: 381-383.

6. Pointing JD, Watterss GG, Forrey RR, Stangly WL, Jackson R (1966) Osmotic dehydration of fruits. J Food Sci Technol 20: 125-128

7. Biswal RN, Maguer Le (1989) Mass transfers in plant material in contact with aqueous solution of ethanol and sodium chloride equilibrium data. $\mathrm{J}$ Food Process Eng 11: 159-176.

8. Dixon GM, Jen JJ, Paynter VP (1976) Tasty apple slices result from combined osmotic dehydration and vacuum drying process. Fd Product Devt 10: 60-66.

9. Ahmed J, Choudhary DR (1995) Osmotic dehydration of papaya. Indian Food Packer 49: 5-11.

10. Bolin HR, Huxsoll CC, Jackson R (1983) Effect of osmotic agents and concentration on fruit quality. J Food Sci Technol 48: 202-205.

11. Chadha KL, Reddy BMC, Shikhamany SD (1998) Pineapple. Indian Council of Agricultural Research, New Delhi, India.

12. Chavan UD, Prabhukhanolkar AE, Pawar VD (2010) Preparation of osmotic dehydrated ripe banana slices. J Food Sci Technol 47: 380-386.

13. Dhingra D, Kadam DM, Singh J, Patil RT (2013) Osmotic dehydration of pineapple with sucrose: Mass transfer kinetics. J Agril Eng 50: 14-18.

14. FAO (2012) Food and Agriculture Organization, Area and production data Rome, Italy.

15. Flink JM (1975) Processing conditions for improved flavour quality of freezedried foods. J Agric Food Chem 23: 1019-1026.

16. Giangiacomo R, Torreggiani D, Abbo E (1987) Osmotic dehydration of fruit Part I. Sugar exchange between fruit and extracting syrup. J Fd Process Preserv 11: 183-195.

17. Hawkes J, Flink JM (1978) Osmotic concentration of fruit slices prior to freeze dehydration. J Food Process Pres 2: 265-284.

18. Jain SK, Verma RC, Murdia LK, Jain HK, Sharma GP (2011) Optimization of process parameters for osmotic dehydration of papaya cubes. J Food Sci Technol 48: 211-217.

19. Kar A, Gupta DK (2001) Osmotic dehydration characteristics of button mushrooms. J Food Sci Technol 38: 352-357.

20. Tomar MC, Singh UB, Singh S (1990) Studies on osmotic dehydration of pear Progr Hort 22: 77-83.

21. Lal G, Pruthi JS (1955) Ascorbic acid retention in pineapple products. Indian J Hort 12: 137-141.

22. Lenart A, Flink JM (1984) Osmotic concentration of potato. Criteria for the end point of the osmotic process. J Food Sci Technol 19: 45-63.

23. Lerici CR, Pinnavaia G, Rosa MD, Bartolucci L (1985) Osmotic dehydration of fruit: Influence of osmotic agents on drying behavior and product quality. J Food Sci 50: 1217-1219.

24. Kumar SP, Sagar VR (2009) Effect of osmosis on chemical parameters and sensory attributes of mango, guava slices and aonla segments. Indian J Hort 66: 53-57.

25. Lodh SB, Selvaraj Y, Chadha KL, Melanta KR (1972) Biochemical changes associated with growth and development of pineapple fruits var: Kew-II changes in carbohydrate and mineral constituents. Indian J Hort 29: 287-292.

26. Mehta GL, Tomar MC (1980a) Studies on dehydration of tropical fruits in Uttar Pradesh: II. Guava (Psidium guajava L.). Indian Food Packer 34: 8-11.
27. Chakraverty A, Mujumdar AS, Ramaswamy HS (2003) Drying of fruits, vegetables and spices. Handbook of Post-Harvest Technology, Marcel Dekker Inc, New York, USA.

28. Salunkhe DK, Bolin HR, Reddy NR (1991) Storage, processing and nutritiona quality of fruits and vegetables. CRC Press, Boca Raton, Florida, USA.

29. Mehta GL, Tomar MC, Gawar BS (1982) Studies on dehydration of pineapple in Uttar Pradesh. Indian Food Packer 36: 35-40.

30. Ozdemir M, Ozen B, Dock L, Floros J (2008) Optimization of osmotic dehydration of diced green peppers by response surface methodology. LTWFood Sci Technol 41: 2044-2050.

31. Rahman MS, Lamb J (1990) Osmotic dehydration of pineapple. J Food Sci Technol 27: 150-152.

32. Pokharkar SM, Prasad S (1998) Mass transfer during osmotic dehydration of banana slices. J Food Sci Technol 35: 336-338.

33. Mehta GL, Tomar MC (1980) Studies on dehydration of tropical fruits in Uttar Pradesh. III. Papaya. Indian Food Packer 34: 12-15.

34. Fernandes F, Linhares Jr FE, Rodrigues S (2008) Ultrasound as pre-treatment for drying of pineapple. Ultrason. Sonochem 15: 1049-1054

35. Kim MH, Taledo RT (1987) Effect of osmotic dehydration and high temperature fluidizedbed drying on properties of dehydrated rabbit eye blueberries. J Food Sci Technol 34: 230-232.

36. Pokharkar SM, Prasad S (1998) Water desorption isotherms of osmotically concentrated pineapple. J Food Sci Technol 35: 518-520.

37. Rahman MS (1992) Osmotic dehydration kinetics of foods. Indian Food Ind 11: $20-24$.

38. Pokharkar SM, Prasad S (2002) Air drying behaviour of osmotically dehydrated pineapple. J Food Sci Technol 39: 384-387.

39. Raout Wack AL (1994) Recent advances in the osmotic dehydration of fruits. Food Sci Technol 5: 255-260.

40. Rashmi HB, Doreyappa GIN, Mukunda GK (2005) Studies on osmo-air dehydration of pineapple fruits. J Food Sci Technol 42: 64-67.

41. Saxena S, Mishra BB, Chander R, Sharma A (2009) Shelf stable intermediate moisture pineapple (Ananas comosus) slices using hurdle technology. LWTFood Sci Technol 42: 1681-1687.

42. Rosa MD, Giroux F (2001) Osmotic treatments and problems related to the solution management. J Food Eng 49: 223-236.

43. Corzo O, Gomez ER (2004) Optimization of osmotic dehydration of cantaloupe using desired function methodology. J Food Eng 64: 213-219.

44. Kumar SP, Sagar VR (2008) Quality of osmo-vac dehydrated ripe mango slices influenced by packaging material and storage temperature. J Sci Ind Res 67 $1108-1114$.

45. Fernandez E, Monserrat S, Sluka E (2005) Conservation technologies applying combined methods in pepper, bean and eggplant. Rev Fac Cienc Agrar, Univ Nac Cuyo 37: 73-81.

46. Sodhi NS, Singh N (2006) Osmotic dehydration kinetics of carrots. J Food Sci Technol 43: 374-376.

47. Surabhi R, Pal RK, Jayachandran KS (2007) Optimization of process parameters for osmotic dehydration of pineapple slices. Indian J Hort 64: 304-308.

48. Silva WP, Silva CMDPS, Lins MAA, Gomes JP (2014) Osmotic dehydration of pineapple (Ananas comosus) pieces in cubical shape described by diffusion models. LWT-Food Sci Technol 55: 1-8. 